\title{
Analisis Faktor Kesulitan Guru SD dalam Penerapkan Model Pembelajaran Inovatif Berbasis Konstruktivisme pada Proses Belajar Mengajar di SDNegeri Kota Malang
}

\author{
Yulita Pujiharti \\ Program Studi Pendidikan Ekonomi dan Kewirausahaan IKIP Budi Utomo Malang \\ Jalan Citandui 46 Malang \\ Loesita Sari \\ Program Studi Pendidikan Ekonomi dan Kewirausahaan IKIP Budi Utomo Malang \\ Jalan Citandui 46 Malang \\ Nurrahman \\ Program Studi Pendidikan Ekonomi dan Kewirausahaan IKIP Budi Utomo Malang \\ Jalan Citandui 46 Malang
}

\begin{abstract}
The ultimate goal of all government programs in education, including certification program is to improve the quality of education, resulting in Indonesian human resources are superior. Surprising findings of several previous studies, that almost most teachers teach to the learning patterns of the old classical learning models. Therefore the aim of this study was to analyze factors Elementary School Teacher Difficulties In Implementing Innovative Learning Model Based On Constructivist Teaching and Learning in Elementary School Malang. The method used is to use mapping and analyzing several factors that could be expected to influence the pattern of applied learning classroom teachers. The study population is a public elementary school teacher Malang number 196 school.Tehnik scattered cluster area sampling is random sampling with a sample of 125 teacher. Analisis by mapping the data, look for the percentage of each district and for the use of multiple regression analyzes durbin Watson method. Results of Analysis states that 1) Map pattern of teaching is the most innovative teachers in District Blimbing 2 ) Teacher Elementary School in Malang assume that the level of difficulty of planning and implementation of innovative teaching model at the level sedang.3 ) Variables that affect the pattern of Innovative Learning constructivism is based on variable difficulty in the preparation of lesson plans and teachers' confidence in the ability of students to do the teaching and learning process based Innovative constructivism, while 18 others are considered predictors of no effect .
\end{abstract}

Keyzords: Difficulty Teachers, Innovative Learning Model

Perubahan kebijakan pendidikan di Indonesia yang sangat besar pada tahun terakhir ini, harusnya berdampak positif pada dunia pendidikan.Mulai dari dikeluarkannya UndangUndang Guru No. 20 ahun 2003, sertifikasi guru, sampai APBN utuk pendidikan yang dinaikkan $20 \%$. Tentu saja harapan pemerintah adalah peningkatan kualitas pendidikan di Indonesia. Akan tetapi bila kita melihat hasil peringkat pendidikan Indonesia malah menurun (dari peringkat 65 menjadi peringkat 69 tahun 2010). Padahal tahun 2009 ini program sertifikasi sudah hampir selesai, berarti sebagian besar guru,termasuk guru SD sudah tersertifikasi, kesejahteraan terjamin, yang logikanya, pola pembelajarannya harusnya lebih berkualitas, Dengan pola pembelajaran yang berkualitas, tentu saja yang diharapkan kualitas pendidikan meningkat.

Sebagai pendidik, kita memahami bahwa Proses Belajar Mengajar yang profesional akan berdampak pada peningkatan kualitas lulusan. Guru semestinya memahami bahwa profesinya adalah melakukan pembelajaran. Oleh sebab itu, setiap guru sebaiknya belajar ilmu atau metode pembelajaran yang bagaimana yang diperlukan sebagai dasar untuk mengajar agar dapat dikategorikan sebagai guru yang profesional. Minimal dalam model pembelajaran guru harusnya memakai model inovatif yang 
menempatkan siswa sebagai sentral dari PBM sehingga guru bisa menumbuhkan kemampuan siswa dan menggali potensi siswa. Dalam proses belajar mengajar peran guru sangatlah dibutuhkan untuk mendukung terciptanya suasana mengajar yang menyenangkan, aktif dan memungkinkan anak berprestasi secara maksimal. Guru harus bisa membuat peserta didik merasa nyaman dan berpartisipasi aktif dalam pembelajaran. Partisipasiaktif maksudnya adalah keterlibatan siswa dalam menyikapi, memahami, mencerna materi yang disajikan dalam proses belajar. Agar gaya mengajar guru ini berpengaruh baik terhadap proses belajar siswa-siswanya maka guru dituntut untuk mengetahui dan memahami model-model pembelajaran terkini dan bisa menerapkankan dalam proses belajar mengajar dikelas.

Berdasarkan hasil penelitian dari peneliti terdahulu dengan judul "Perbedaan Motivasi Dan Kinerja Guru Yang Telah Tersertifikasi Dengan Yang Belum Tersertifikasi" pada Guru SD di Kota Malang, didapatkan hasil tidak ada perbedaan dari motivasi dan kinerja guru tersertifikasi dan yang belum tersertifikasi. Hal itu menunjukkan bahwa kebijakan pemerintah untuk menaikkan kesejahteraan guru belum membawa dampak positif bagi dunia pendidikan. Guru yang tersertifikasi seharusnya lebih professional dari pada yang belum tersertifikasi khususnya dalam pengelolaan proses pembelajaran yang merupakan inti dari proses belajar mengajar, kenyataan dilapangan menyatakan bahwa pengetahuan guru baik yg sudah maupun yang belum tersertifikasi tentang PBM inovatif berbasis konstruktivisme sangat minim. Hasil penelitian waktu itu, mereka lebih sering mengguakan model klasik (behavioristik).

Penelitian ini penting untuk dilakukan dengan tujuan untuk mengetahui factor faktor yang membuat guru merasa kesulitan dalam menerapkan model pembelajaran inovatif berbasis konstruktivisme. Penelitian ini, dilakukan pada guru SD di Kota Malang lebih dahulu dikarenakan kota ini merupakan kota pendidikan dimana pada daerah tersebut sangat banyak perguruan-perguruan tinggi dan sekolah-sekolah dari berbagai tingkatan, dimana seharusnya bisa menghasilkan prestasi yang baik dalam bidang pendidikan. Tujuan penelitian ini adalah menganalis faktor kesulitan guru dalam menerapkan model pembelajaran inovatif berbasis konstruktivisme pada proses belajar mengajar Guru SD di Kota Malang.

Kegiatan pembelajaran adalah kegiatan yang melibatkan peserta didik dalam proses mental dan fisik melalui interaksi antar peserta didik, peserta didik dengan guru, lingkungan dan sumber belajar lainnya dalam rangka pencapaian kompetensi dasar pembelajaran. Dalam melakukan pembelajaran membutuhkan strategi yang dalam dunia pendidikan dinamakan strategi pembelajaran. Strategi pembelajaran merupakan pola kegiatan pembelajaran berurutan yang diterapkan dari waktu ke waktu dan diarahkan untuk mencapai suatu hasil belajar siswa yang diinginkan. Dalam menjalankan strategi pembelajaran tersebut, paling tidak seorang guru harus paham dengan 5 ketrampilan dasar mengajar, mulai dari membuka dan menutup pelajaran, ketranpilan menjelaskan, ketrampilan mengadakan variasi, ketrampilan bertanya serta ketrampilan melakukan penguatan. Bila guru sudah paham dengan strategi dasar tersebut maka guru harus bisa melakukan dengan inovatif. Inovatif (innovative) yang berartinew ideas or techniques, merupakan kata sifat dari inovasi (innovation) yang berarti pembaharuan, juga berasal dari kata kerja innovate yang berarti make change. Pembelajaran inovatif adalah pembelajaran yang dikemas oleh pebelajar atas dorongan gagasan barunya yang merupakan produk dari learning how to learn untuk melakukan langkah-langkah belajar, sehingga memperoleh kemajuan hasil belajar. Pembelajaran inovatif juga mengandung arti pembelajaran yang dikemas oleh guru atau instruktur lainnya yang merupakan wujud gagasan atau teknik yang dipandang baru agar mampu memfasilitasi pebelajar untuk memperoleh kemajuan dalam proses dan hasil belajar. Berdasarkan definisi secara harfiah pembelajaran inovatif tersebut, tampak di dalamnya terkandung makna pembaharuan. Inovasi pembelajaran muncul dari perubahan paradigma pembelajaran. Perubahan paradigma pembelajaran berawal dari hasil refleksi terhadap eksistensi paradigma lama yang mengalami anomali menuju paradigma baru yang dihipotesiskan mampu memecahkan masalah. Paradiqma lama dan baru tersebut berakar dari dua aliran filsafat pendidikan yang mempengaruhi arah pengembangan teori dan praktik pendidikan adalah aliran behavioristik dan konstruktivistik. Aliran behavioristik 
menekankan terbentuknya perilaku yang tampak sebagai hasil belajar, sedangkan aliran konstruktivistik menekankan pembentukan perilaku internal yang sangat mempengaruhi perilaku yang tampak. Teori behavioristik berarti pembelajaran siswa yang berpusat pada guru, bersifat mekanistik, dan hanya berorientasi pada hasil yang dapat diamati dan diukur. Sedangkan aliran konstruktivisme menyatakan bahwa pembentukan pengetahuan memandang subyek aktif menciptakan struktur-struktur kognitif dalam interaksinya dengan lingkungan. Dengan bantuan struktur kognitifnya ini, subyek menyusun pengertian realitasnya. Pembelajaran yang mengacu kepada teori belajar konstruktivisme lebih menfokuskan pada kesuksesan siswa dalam mengorganisasikan pengalaman mereka. Bukan kepatuhan siswa dalam refleksi atas apa yang telah diperintahkan dan dilakukan oleh guru. Dengan kata lain, siswa lebih diutamakan untuk mengkonstruksi sendiri pengetahuan mereka melalui asimilasi dan akomodasi.

Agen pembaharuan dan pembelajaran tersebut adalah Guru. Sebagai unsur yang berada di garda terdepan pendidikan, begitu banyak sebutan sanjungan yang diberikan kepada guru seperti "Guru pejabat mulia", "pahlawan tanpa tanda jasa", "guru sebagai jabatan profesional", "guru sebagai sumber teladan", "guru sebagai pengukir masa depan bangsa". Tentunya ungkapan-ungkapantersebut merupakan upaya untuk memotivasi para guru dalam melaksanakan tugasnya, meskipun dalam kenyataannya banyak yang mempersepsi ungkapan-ungkapan tersebut justru merupakan sanjungan yang tidak sesuai dengan realitas sehingga membuat guru tersandung. Guru dipandang memiliki prestise terhormat., akan tetapi sebagai profesi yang rendah dengan imbalanyang tidakmemadai. Dengan posisiyang sangat strategis di garda terdepan pendidikan, seharusnya guru mendapat perhatian yang sungguh-sungguh dalam hal pembinaan profesional dan dukungan kesejahteraan melalui manajemen pendidikan yang kondusif. Menurut Carl D. Glickman (1990) guru masih berada di lingkungan kerja yang disebut "The legacy of the One-Room Schoolhouse" atau "warisan satu-kamar bangunan sekolah". Dikatakan bahwa guru melakukan tugas kerjanya berada dalam sebuah ruangan yang dibatasi empat dinding di kawasan bangunan sekolah.
Aktivitas guru dari menit ke menit dari hari ke hari dan dari tahun ke tahun berada dalam batas tembok empat dinding menata seluruh kelas, memeriksa kehadiran murid, mengajar, menilai, dsb. Hal itu membuat daya inovatif guru sulit untuk berkembang. Apalagi guru di Indonesia, yang kesehariannya masih di bebani pekerjaan lain untuk menambah pundi-pindi rupiah. Sehingga mereka kurang mempunyai waktu untuk memikirkan inovasi.

Inovasi pembelajaran menuntut guru untuk memahami berbagai model pembelajaran berbasis konstruktivisme, menyiapkannya dalam bentuk RPP serta mempraktekkannya dikelas pada saat proses belajar mengajar. Berbagai model pembelajaran inovatif tersebut sebenarnya sudah banyak disosialisasikan dan mudah dicari dari berbagai sumber seperti buku, internet, seminar dan lain-lain. Akan tetapi, berdasarkan penelitian (Yulita ;2011) yang berjudul Pengaruh Sertifikasi terhadap Kinerja Guru SD se Kota Malang didapatkan temuan bahwa guru SD jarang mengetahui jenis-jenis model pembelajaran yang berbasis konstruktivisme tersebut. Guru SD masih jarang menggunakan model pembelajaran inovatif berbasis konstruktivisme. Kebanyakan dari para guru tersebut, bahkan yang sudah ditraining, ataupun sering mengikut training, mereka kembali ke model pembelajaran klasik pada saat mereka sudah benar-benar melakukan PBM.

Begitu juga penemuan penelitian Lestiana, $\mathrm{H}$ dalam penelitiannya yang berjudul Pengaruh Kompetensi Guru Dalam Meningkatkan mutu lulusan Di SD Negeri Rayon Kecamatan Ilir Barat 1 Palembang menyatakan bahwa "Ketidak efektifan proses belajar yan terlalu menekan pada penguasaan teori dan kognisi adalah akibat lain dari rendahnya kualitas lulusan. Beban pelajaran yang perlu terstruktur dan banyaknya jumlah siswa dalam satu kelas telah menyebabkan jumlah proses pembelajran yang tidak sesuai dengan konsisi dan perubahan sosial keadaan ini menjadikan proses belajar yang terlalu monoton, tidak menarik dan tidak ada inovasi dan tidak mampu mengembangkakn kekreatifitasan siswa, guru, kepalas sekolah dalam mengembangkan inovasi pendekatan pembelajaran". Daribeberapa penelitian tersebut disimpulkan bahwa guru masih mengalami kesulitan dalam melaksankaan model pembelajaran inovatif berbasis konstruktivisme. Oleh karena itu pada penelitian ini, peneliti 
52 | Yulita Pujiharti, Loesita Sari, \& Nurrahman, Analisis Faktor Kesulitan Guru SD dalam ...

menganalis kesulitan guru tersebut, sehingga bisa dicari jalan pemecahannya.

\section{METODE}

Penelitian ini akan menggunakan beberapa jenis rancangan penelitian, yaitu (1) deskriptif, (2) kuantitatif. Rincian jenis rancangan, subjek, variabel, instrumen, dan analisis data penelitian disajikan sebagai berikut.

\section{Rancangan Penelitian}

Dalam penelitian ini ada 2 rancangan penelitian :

1) Penelitian ini termasuk penelitian pemetaan cara mengajar guru SD Negeri di Kota Malang (mapping teacher teach) untuk mendapatkandatalengkaptentang cara mengajar guru SD di kota Malang, sebagai dasar langkah selanjutnya untuk peningkatan kualitas pembelajaran guru SD

2) Metode ini digunakan untuk menganalisis fakor kesulitan guru dalam menerapkan model pembelajaran inovatif berbasis konstruktivisme adalah dengan pemetaan satu persatu kesulitan yang dihadapi oleh guru saat merencanakan dan melaksanakan model pembelajaran inovatif.

\section{Waktu penelitian}

Waktu penelitian mulai bulan Januari Desember 2013.

\section{Luaran Penelitian}

1) Peta model pembelajaran yang biasa dipakai Oleh Guru SD di Kota Malang

2) Mengetahui kesulitan yang dihadapi oleh Guru dalam menerapkan pembelajaran model inovatif berbasis konstruktivisme

\section{Populasi dan Sampel Penelitian}

Populasi adalah keseluruhan dari unsurunsur yang memiliki satu atau beberapa karakteristik yang sama.Berdasarkan pendapat tersebut diatas dapat disimpulkan bahwa poulasi adalah keseluruhan subyek penelitian yang memiliki cirri-ciri yang akan diteliti . Populasi dari penelitian ini adalah Guru Sekolah Dasar Negeri se Kota Malang Sejumlah 2525 yang tersebar di 196 sekolah.

Sedangkan tehnik pengambilan sampel adalah Cluster area random sampling, dimana dari 5 Kecamatan semua diambil secara acak 5 SD, Kemu-dian dari ke 5 SD tersebut diambil secara acak 5 guru. Sehingga mendapat-kan sampel sebagai berikut :

Tabel 1. POPULASI DAN SAMPEL PENELITIAN

\begin{tabular}{clccc}
\hline No & Kecamatan & SDN & SD Sampel & Guru sampel \\
\hline 1 & Klojen & 26 & 5 & $5 \times 5=25$ guru \\
2 & Blimbing & 56 & 5 & $5 \times 5=25$ guru \\
3 & Kedungkandang & 54 & 5 & $5 \times 5=25$ guru \\
4 & Lowokwaru & 52 & 5 & $5 \times 5=25$ guru \\
5 & Sukun & 54 & 25 & $5 \times 5=25$ guru \\
\hline & & 242 & & 125 guru \\
\hline
\end{tabular}

\section{Subyek Penelitian}

Subjek penelitian guru SD se Kota Malang untuk memperoleh data pola pembelajaran serta menganalisis kesulitan guru dalam menerapkan pembelajaran model inovatif berbasis konstruktivisme pada guru SDNegeri di Kota Malang. Lokasi dan subjek penelitian yang dilakukan pada penelitian survey terdiri atas Guru SD di Kota Malang.

\section{Instrumen Penelitian}

Instrument untukmenilaiPolaMembelajaran yang dilakukan oleh guru saat mengajar di kelas, untuk memetakan apakah guru saat mengajar dikelas memakai model pembelajaran konstruktivisme seperti yang diharuskan dalam KTSP ataukah hanya dengan model pembelajaran konvensional adalah dengan : 
a. Chek list yang akan diisi oleh obserser mengenai pola pembelajaran dan ketrampilan guru dalam mengajar, ceklist berisi 5 ketrampilan guru dalam pengelolaan pembelajaran dikelas secara inovatif mulai dari :
a) Keterampilan membuka dan menutup pelajaran
b) Keterampilan menjelaskan inovatif
c) Keterampilan mengadakan variasi model pembelajaran inovatif
d) Kerampilan bertanya pada model pembelajaran inovatif
e) Keterampilan memberikan penguatan

b. Self assement yang berupa kuesioner yang akan diisi guru sendiri untuk menggali :

Kesulitan penerapan model pembelajaran inovatif berbasis konstruktivisme

\section{Analisis Data}

Suharsimi, A dalam buku Metode Penelitian (2010 : 278) menyatakan setelah data terkumpul dari hasil pengumpulan data, perlu segera digarap oleh staf peneliti, khususnya yan bertugas mengolah data. Didalam buku-buku lain sering disebut pengolahan data. Secara garis besar, pekerjaan analisis data meliputi 3 langkah yaitu :

\section{Persiapan}

2. Tabulasi

3. Penerapan data sesuai dengan pendekatan penenelitian

Pada tahap persiapan dilakukan pemeriksaan terhadap setiap kuesioner apakah telah diisi sesuai dengan petunjuk sebelumnya.Jika terdapat kuesioner yang tidak sesuai dengan dengan petunjuk pengisian atau tidak relevan jawabannya maka kuesioner tersebut tidak diikutsertakan dalam analisis data. Kemudian dilakukan tabulasi, dihitung dan dianalisis.

Pola pembelajaran guru dikelas dinilai oleh observer pada saat guru melaksanakan proses belajar mengajar dikelas. Penilaian dilakukan dengan checklist ketrampilan mengajar yang sudah di modifikasi sehingga menjadi pola mengajar yg inovatif konstrukrivisme. Adapun instrument dan tehnik penilaiannya sepeti tercantum pada table 2. Dibawah ini :

Tabel.2. Cheklist Pola Pembelajaran guru dikelas dinilai sbb :

\begin{tabular}{|c|c|c|}
\hline No & Ketrampilan Mengajar Yang dinilai & Tehnik Penilaian \\
\hline 1 & $\begin{array}{l}\text { Rubrik penilaian keterampilan membuka dan } \\
\text { menutup pelajaran inovatif (set induction and } \\
\text { closure) }\end{array}$ & $\begin{array}{l}\text { - } \quad \text { Skor Maksimal } 2 \text { X } 19=38 \\
\text { Nilai }=\frac{\text { Skor Perolehan }}{38} \times 100=. .\end{array}$ \\
\hline 2 & $\begin{array}{l}\text { Rubrik penilaian keterampilan menjelaskan } \\
\text { inovatif (explaining skill) }\end{array}$ & $\begin{array}{c}\text { - Skor maksimal } 2 \text { x } 12=24 \\
\text { Skor perolehan }\end{array}$ \\
\hline & & $\begin{array}{ll}\text { Nilai }= & \times 100\end{array}$ \\
\hline 3 & $\begin{array}{l}\text { Rubrik penilaian keterampilan mengadakan } \\
\text { variasi model pembelajaran inovatif(variation } \\
\text { skill) }\end{array}$ & $\begin{array}{l}\text { - Skor maksimal } 2 \times 15=30 \\
\qquad \text { Nilai }=\frac{\text { Skor Perolehan }}{30} \times 100=.\end{array}$ \\
\hline 4 & $\begin{array}{l}\text { Rubrik penilaian keterampilan bertanya pd } \\
\text { model pemb inovatif } \\
\text { (question skill) }\end{array}$ & $\begin{array}{l}\text { - } \quad \text { Skor Maksimal } 2 \text { X } 19=18 \\
\text { Nilai }=\frac{\text { Skor Perolehan }}{18} \times 100=. .\end{array}$ \\
\hline 5 & $\begin{array}{l}\text { Rubrik penilaian keterampilan memberi pen- } \\
\text { guatan } \\
\text { (reinforcement skill) }\end{array}$ & $\begin{array}{l}\text { - } \quad \text { Skor Maksimal } 2 \text { X } 19=8 \\
\text { Nilai }=\frac{\text { Skor Perolehan }}{8} \times 100=. .\end{array}$ \\
\hline
\end{tabular}

Skor Nilai $\underline{A+B+C+D+E}=$ Nilai Akhir

5

Nilai akhir dibagi menjadi 5 (skala likert) dan menjadi indikator dari inovatif/tidaknya model pembelaran guru di kelas, sbb : 
$54 \mid$ Yulita Pujiharti, Loesita Sari, E Nurrahman, Analisis Faktor Kesulitan Guru SD dalam ...

Tabel 3. Tingkat kemampuan guru dalam pengelolaan pembelajaran Inovatif dikelas:

\begin{tabular}{cc}
\hline $\begin{array}{c}\text { Standart Kemampuan } \\
\text { Inovatif Guru }\end{array}$ & Klasifikasi \\
\hline $0-20$ & Sangat Tidak Inovatif \\
$21-40$ & Tidak Inovatif \\
$41-60$ & Biasa \\
$61-80$ & Inovatif \\
$81-100$ & Sangat Inovatif \\
\hline
\end{tabular}

Analisis kesulitan guru dalam pembelajaran inovatif dilakukan dengan memberikan kuesioner yang diisi oleh guru. Adapun instrument kuesionernya dapat dijabarkan sebagai berikut :

Tabel 4. Kuesioner kesulitan guru dalam pembelajaran inovatif

\begin{tabular}{lc}
\hline \multicolumn{1}{c}{ Jenis kesulitan } & Point angket \\
\hline $\begin{array}{l}\text { Pembuatan RPP inovatif - kon- } \\
\text { struktivisme }\end{array}$ & $1,8,14,17$ \\
$\begin{array}{l}\text { Manajemen waktu bila meng- } \\
\text { gunakan model pembelajaran } \\
\text { inovatif - konstruktivisme }\end{array}$ & $2,15,16,19$ \\
$\begin{array}{l}\text { Kerumitan pelaksanaan model } \\
\text { pembelajaran konstruktivisme }\end{array}$ & $3,7,9,18$ \\
$\begin{array}{l}\text { Biaya pelaksanaan model pem- } \\
\text { belajaran konstruktivisme }\end{array}$ & \multicolumn{1}{l}{$\begin{array}{l}\text { Pengetahuan guru tentang } \\
\text { model pembelajaran inovatif - } \\
\text { konstruktivisme }\end{array}$} \\
$\begin{array}{l}\text { Kepercayaan guru kepada mu- } \\
\text { rid untuk membangun konsep } \\
\text { secara konstruktivis }\end{array}$ & $6,12,13,20$ \\
\hline
\end{tabular}

Adapun indikator tingkat kesulitan guru sebagai berikut :

Tabel 5. Kesulitan - kesulitan penerapan model pembelajaran inovatif berbasis konstruktivisme

\begin{tabular}{|c|c|}
\hline $\begin{array}{l}\text { Kesulitan Guru } \\
\text { menerapkan } \\
\text { model pembelaja- } \\
\text { ran inovatif }\end{array}$ & Tingkat kesulitan \\
\hline $20-36$ & $\begin{array}{c}\text { Sangat Kesulitan / Sangat } \\
\text { Tidak Inovatif }\end{array}$ \\
\hline $37-52$ & Kesulitan / tidak Inovatif \\
\hline $53-68$ & Biasa \\
\hline $69-84$ & Mudah / Inovatif \\
\hline $85-100$ & $\begin{array}{l}\text { Sangat Mudah / Sangat } \\
\text { Inovatif }\end{array}$ \\
\hline
\end{tabular}

Sedangkan untuk menganalisis faktor kesulitan guru dalam menerapkan pembelajaran model inovatif berbasis konstruktivisme akan dilakukan dengan analisis per item dari factor yang diduga menjadi kesulitan guru dengan menggunakan Regresi Berganda metode Durbin Watson

\section{HASIL}

Peta Model Pembelajaran (pola mengajar) GuruSD se Kota Malang

Berdasarkan pengamatan beberapa observer maka didapat hasil cara mengajar guru diberbagai kecamatan di kota Malang sbb:

Tabel 6.Pola Mengajar Guru Di Kecamatan Klojen

\begin{tabular}{cccc}
\hline $\begin{array}{c}\text { Standart } \\
\text { Kemampuan } \\
\text { Inovatif } \\
\text { Guru }\end{array}$ & Klasifikasi & jumlah & persentase \\
\hline $0-20$ & $\begin{array}{c}\text { Sangat Tidak } \\
\text { Inovatif }\end{array}$ & 6 & 24 \\
& & \\
$21-40$ & $\begin{array}{c}\text { Tidak Inovatif } \\
\text { Agak Inovatif }\end{array}$ & 15 & 60 \\
$41-60$ & $\begin{array}{c}\text { Agak } \\
\text { Inovatif }\end{array}$ & 1 & 42 \\
$81-80$ & Sangat Ino- & 0 & 0 \\
& vatif & & \\
\hline & & 25 & 100 \\
\hline
\end{tabular}

Berdasarkan data tersebut didapatkan data bahwa guru di Kecamatan Klojen yang menggunakan model pembelajaran inovatif sangat sedikit hanya $4 \%$,yang agak inovatif $12 \%$, rata 2 guru masih menggunakan cara yang tidak inovatif.

Tabel 7. Pola Mengajar Guru Di Kecamatan Sukun

\begin{tabular}{cccc}
\hline $\begin{array}{c}\text { Standart } \\
\text { Kemampuan } \\
\text { Inovatif Guru }\end{array}$ & Klasifikasi & jumlah & persentase \\
\hline $0-20$ & $\begin{array}{c}\text { Sangat Tidak } \\
\text { Inovatif }\end{array}$ & 1 & 4 \\
$21-40$ & $\begin{array}{c}\text { Tidak Ino- } \\
\text { vatif } \\
\text { Agak Ino- } \\
\text { vatif } \\
\text { Inovatif }\end{array}$ & 19 & 76 \\
$61-80$ & $\begin{array}{c}\text { Sangat Ino- } \\
\text { vatif }\end{array}$ & 0 & 16 \\
$81-100$ & & 25 & 100 \\
\hline
\end{tabular}


Berdasarkan data tersebut didapatkan data bahwa guru di kecamatan Sukun yang menggunakan model pembelajaran inovatif sangat sedikit hanya $4 \%$, agak inovatif $16 \%$ rata 2 guru masih menggunakan cara yang tidak inovatif.

Tabel 8. Pola Mengajar Guru Di Kecamatan Lowokwaru

\begin{tabular}{cccc}
\hline $\begin{array}{c}\text { Standart } \\
\text { Kemam- } \\
\text { puan Ino- } \\
\text { vatif Guru }\end{array}$ & Klasifikasi & jumlah & persentase \\
\hline $0-20$ & $\begin{array}{c}\text { Sangat Tidak } \\
\text { Inovatif }\end{array}$ & 0 & 0 \\
& & \\
$21-40$ & Tidak Inovatif & 0 & 0 \\
$41-60$ & Agak Inovatif & 5 & 20 \\
$61-80$ & Inovatif & 15 & 60 \\
$81-100$ & $\begin{array}{c}\text { Sangat Ino- } \\
\text { vatif }\end{array}$ & 5 & 20 \\
\hline & & 25 & 100 \\
\hline
\end{tabular}

Berdasarkan data tersebut didapatkan data bahwa guru di kecamatan Lowokwaru sudah sangat inovatif diaman $60 \%$ masuk katagori inovatif dan $20 \%$ sangat inovatif

Tabel 9. Pola Mengajar Guru Di Kecamatan Ke-

\begin{tabular}{cccc}
\multicolumn{4}{c}{ dung kandang } \\
\hline $\begin{array}{c}\text { Standart } \\
\text { Kemam- } \\
\text { puan Ino- } \\
\text { vatif Guru }\end{array}$ & Klasifikasi & jumlah & persentase \\
\hline $0-20$ & $\begin{array}{c}\text { Sangat Tidak } \\
\text { Inovatif }\end{array}$ & 0 & 0 \\
& & \\
$21-40$ & $\begin{array}{c}\text { Tidak Inovatif } \\
41-60\end{array}$ & 0 & 0 \\
$61-80$ & Agak Inovatif & 4 & 16 \\
Inovatif & 16 & 64 \\
\hline
\end{tabular}

\begin{tabular}{|c|c|c|c|}
\hline $\begin{array}{c}\text { Standart } \\
\text { Kemam- } \\
\text { puan Ino- } \\
\text { vatif Guru }\end{array}$ & Klasifikasi & jumlah & persentase \\
\hline \multirow[t]{2}{*}{$81-100$} & Sangat Inovatif & 5 & 20 \\
\hline & & 25 & 100 \\
\hline
\end{tabular}

Berdasarkan data tersebut didapatkan data bahwa guru di kecamatan Kedungkandang sudah sangat inovatif dimana $64 \%$ masuk katagori inovatif dan $20 \%$ sangat inovatif, hanya $18 \%$ yang terkatagori kurang inovatif

\section{Tabel 10.Pola Mengajar Guru Di Kecamatan Blimbing}

\begin{tabular}{cccc}
\hline $\begin{array}{c}\text { Standart } \\
\text { Kemampuan } \\
\text { Inovatif Guru }\end{array}$ & Klasifikasi & jumlah & persentase \\
\hline $0-20$ & $\begin{array}{c}\text { Sangat } \\
\text { Tidak Ino- } \\
\text { vatif } \\
\text { Tidak Ino- } \\
\text { vatif } \\
\text { Agak Ino- } \\
\text { vatif } \\
41-60\end{array}$ & 0 & 0 \\
$\quad \begin{array}{c}\text { Inovatif } \\
\text { Sangat } \\
61-80\end{array}$ & 3 & 0 \\
$81-100$ & 22 & 88 \\
Inovatif & 0 & 12 \\
\hline
\end{tabular}

Berdasarkan data tersebut didapatkan data bahwa guru di kecamatan Blimbing sudah sangat inovatif dimana $88 \%$ dalam proses belajar mengajar sudah memakai model inovatif. Setelah dipetakan satu persatu, akan kami sajikan data perbandingan pola megajar guru di berbagai kecamatan di kota Malang :

Tabel 11. Peta Model Pembelajaran Yang Dilakukan Guru SD di Kota Malang

\begin{tabular}{cccccc}
\hline Pola Mengajar & Kec Klojen & Kec Sukun & Kec KdKandang & Kec Lowokwaru & Kec Blimbing \\
\hline Sangat Tidak Inovatif & 24 & 4 & 0 & 0 & 0 \\
Tidak Inovatif & 60 & 76 & 0 & 0 & 0 \\
Agak Inovatif & 12 & 16 & 16 & 20 & 0 \\
Inovatif & 4 & 4 & 64 & 60 & 12 \\
Sangat Inovatif & 0 & 0 & 20 & 20 & 88 \\
\hline
\end{tabular}


56 | Yulita Pujiharti, Loesita Sari, \& Nurrahman, Analisis Faktor Kesulitan Guru SD dalam ...

Berdasakan table diatas didapatkan peta pola mengajar guru yang paling inovatif adalah di Kecamatan Blimbing, sedangkan di Kecamatan Lowokwaru dan Kedungkandang sudah sebagian besar inovatif, untuk di kecamatan Klojen na Sukun pola menagajar guru masih belum inovatif.
Berdasarkan table di atas dapat disimpulkan bahwa di Kecamatan Klojen guru yang merasa sulit menyusun model pembelajaran inovatif ada $36 \%$, sedang $40 \%$ merasa bisa membuatnya dan $12 \%$ menganggap membuat model pembelajaran inovatif itu mudah. Sedangkan di Kecamatan Sukun 52\% Guru SDNegeri merasa kesulitan

Tabel 12. Kecenderungan Model Pembelajaran Yang sering digunakan guru dikelas

\begin{tabular}{ccccccc}
\hline Rentang & Klasifikasi & Kec Klojen & Kec Sukun & Kec KdKandang & Kec Lowokwaru & Kec Blimbing \\
\hline $10-30$ & Konstruktivisme & 6 & 4 & 4 & 4 & 3 \\
$31-50$ & Behavioristik & 17 & 21 & 21 & 21 & 22 \\
\hline
\end{tabular}

Berdasarkan data diatas, sebagian besar guru memiliki pola berpikir bahwa sebenarnya mengajar yang baik adalah berdasar model konstruktivisme. Akan tetapi pada saat mengajar mereka "cenderung behavioristik".

\section{Peta Kesulitan Guru dalam Pembelajaran Ino-} vatif

Setelah memetakan tingkat kompetensi guru diKota Malang, maka penelitimemetakantingkat kesulitan guru dalam melaksanakan model pembelajaraan inovatif. Karena melaksanakan model pembelajaran inovatif berarti RPP nya pun harus mewadahi hal itu. Secara keseluruhan tingkat kesulitan guru dalam melaksanakan model pembelajaran inovatif dipetakan sebagai berikut : dalam melaksanakan model pembelajaran inovatif, hanya $4 \%$ yang mengganggap sangat mudah. Di Kecamatan Kedungkandang 60\% guru menganggap bisa melaksanakan model pembelajaran inovatif, sedangkan di Kecamatan Lowokwaru $60 \%$ merasa bisa membuat model pembelajaran inovatif dan guru di kecamatan Blimbing yang measa kesulitan melaksanakan model pembelajaran inovatif ada $40 \%$.

Tabel 14. Tingkat Kesulitan Guru SD

di Kota Malang dalam melaksanakan model pembelajaran inovatif

\begin{tabular}{ccc}
\hline Tingkat Kesulitan & jumlah & persentase \\
\hline Sangat kesulitan & 1 & $0.8 \%$ \\
kesulitan & 48 & $38.4 \%$ \\
\hline
\end{tabular}

Tabel 13.Peta Kesulitan Guru SD di Kota Malang dalam melaksanakan model pembelajaran inovatif

\begin{tabular}{|c|c|c|c|c|c|c|c|c|c|c|c|}
\hline $\begin{array}{c}\text { Klasifi } \\
\text { kasi }\end{array}$ & $\begin{array}{l}\text { Tk Ke- } \\
\text { sulitan }\end{array}$ & $\begin{array}{c}\text { Kec } \\
\text { Klojen }\end{array}$ & $\%$ & $\begin{array}{c}\text { Kec } \\
\text { Sukun }\end{array}$ & $\%$ & $\begin{array}{c}\text { Kec Kd } \\
\text { Kan- } \\
\text { dang }\end{array}$ & $\%$ & $\begin{array}{c}\text { Kec } \\
\text { Lowok } \\
\text { waru } \\
\end{array}$ & $\%$ & $\begin{array}{c}\text { Kec } \\
\text { Blimb- } \\
\text { ing }\end{array}$ & $\%$ \\
\hline $20-36$ & $\begin{array}{l}\text { Sangat } \\
\text { kesuli- } \\
\tan \end{array}$ & 1 & $4 \%$ & 0 & 0 & 0 & 0 & 0 & 0 & 0 & 0 \\
\hline $37-52$ & $\begin{array}{l}\text { kesuli- } \\
\tan \end{array}$ & 9 & $36 \%$ & 13 & $52 \%$ & 8 & $32 \%$ & 8 & $32 \%$ & 10 & $40 \%$ \\
\hline $53-68$ & $\begin{array}{l}\text { Cukup } \\
\text { mudah }\end{array}$ & 10 & $40 \%$ & 11 & $44 \%$ & 15 & $60 \%$ & 15 & $60 \%$ & 10 & $40 \%$ \\
\hline $69-84$ & mudah & 3 & $12 \%$ & 0 & 0 & 2 & $8 \%$ & 1 & $4 \%$ & 5 & $20 \%$ \\
\hline $85-100$ & $\begin{array}{l}\text { Sangat } \\
\text { mudah }\end{array}$ & 2 & $8 \%$ & 1 & $4 \%$ & 0 & 0 & 1 & $4 \%$ & 0 & 0 \\
\hline SUM & & 25 & $100 \%$ & 25 & $100 \%$ & 25 & $100 \%$ & 25 & $100 \%$ & 25 & $100 \%$ \\
\hline
\end{tabular}




\begin{tabular}{ccc}
\hline Tingkat Kesulitan & jumlah & persentase \\
\hline Cukup mudah & 61 & $48.8 \%$ \\
mudah & 11 & $8.8 \%$ \\
Sangat mudah & 4 & $3.2 \%$ \\
& 125 & 100 \\
\hline
\end{tabular}

Berdasarkan tabel di atas hanya $8.8 \%$ guru tang menganggap mudah melaksanakan model pembelajaran inovatif. Sedangkan $38,4 \%$ menganggap sulit melaksanakan model pembelajaran inovatif dan $48.8 \%$ menyatakan tingkat kesulitannya cukup.

Supaya lebih memahami dimana dimana letak kesulitan guru dalam melaksanakan model pembelajaran inovatif, maka berikut kami pilah lebih detail tentang berbagai kesulitannya sebagai berikut:

Tabel 15. Peta Kesulitan Guru SD Negeri Kota Malang Dalam menerapkan model pembelajaran Inovatif poin 1 - 10

\begin{tabular}{lcccccccccc}
\hline Kecamatan & $\mathbf{1}$ & $\mathbf{2}$ & $\mathbf{3}$ & $\mathbf{4}$ & $\mathbf{5}$ & $\mathbf{6}$ & $\mathbf{7}$ & $\mathbf{8}$ & $\mathbf{9}$ & $\mathbf{1 0}$ \\
\hline Blimbing & 4.20 & 2.84 & 2.84 & 2.88 & 3.20 & 3.32 & 2.80 & 3.36 & 3.08 & 2.92 \\
Kdkandang & 3.61 & 3.43 & 2.79 & 2.88 & 2.81 & 3.13 & 2.67 & 3.17 & 2.96 & 2.44 \\
Lowokaru & 3.66 & 3.38 & 2.87 & 3.24 & 3.11 & 3.13 & 2.67 & 3.01 & 2.52 & 2.10 \\
Sukun & 3.43 & 2.74 & 2.87 & 2.45 & 2.92 & 3.29 & 2.35 & 3.12 & 2.82 & 2.60 \\
Klojen & 3.50 & 3.43 & 3.11 & 3.10 & 3.24 & 3.57 & 2.89 & 2.72 & 2.99 & 2.50 \\
Rata2 se Malang & $\mathbf{3 . 6 8}$ & $\mathbf{3 . 1 6}$ & $\mathbf{2 . 9 0}$ & $\mathbf{2 . 9 1}$ & $\mathbf{3 . 0 6}$ & $\mathbf{3 . 2 9}$ & $\mathbf{2 . 6 8}$ & $\mathbf{3 . 0 8}$ & $\mathbf{2 . 8 8}$ & $\mathbf{2 . 5 1}$ \\
\hline
\end{tabular}

Berdasarkan table diatas dapat disimpulkan bahwa :

Tabel 16. Peta Kesulitan Guru Menurut Guru SD Di Kota Malang point 1 - 10

1 Membuat RPP dengan model Student Active learning cukup mudah

2 Memakai model "student active learning" atau model kelompok pembelajaran kelompok cukup menyita waktu

3 Memakai model "student active learning" atau model kelompok pembelajaran kelompok cukup rumit

4 Menggunakan model "student active learning" atau model kelompok pembelajaran guru harus mengeluaran biaya lebih

5 Pengetahuan Guru tentang model pembelajaran konstruktif cukup banyak

6 Kepercayaan guru bahwa siswanya bisa mencari berbagai teori dan konsep dengan benar dengan model konstruktivis termasuk cukup

7 Guru sebenarnya tidak begitu suka dengan model ceramah

8 Guru yang memakai RPP yang tersedia (berarti tidak inovatif) sedang yang berarti setengah guru memakai RPP tapi setengahnya memodifikasinya

9 Sebagian besar guru merasa kelasnya bisa dimodifikasi bentuk sehingga tidak membosankan

10 Menurut Guru murid / siswa tidak suka modek ceramah 
58 | Yulita Pujiharti, Loesita Sari, E Nurrahman, Analisis Faktor Kesulitan Guru SD dalam ...

Tabel 17. Peta Kesulitan Guru Menurut Guru SD Di Kota Malang point 11 - 20

\begin{tabular}{ccccccccccc}
\hline Kecamatan & $\mathbf{1 1}$ & $\mathbf{1 2}$ & $\mathbf{1 3}$ & $\mathbf{1 4}$ & $\mathbf{1 5}$ & $\mathbf{1 6}$ & $\mathbf{1 7}$ & $\mathbf{1 8}$ & $\mathbf{1 9}$ & $\mathbf{2 0}$ \\
\hline Blimbing & 3.36 & 3.76 & 3.52 & 2.92 & 3.20 & 2.72 & 3.04 & 3.04 & 3.28 & 2.80 \\
Kdkandang & 2.89 & 3.47 & 2.86 & 3.00 & 3.05 & 2.51 & 3.28 & 3.20 & 2.85 & 1.91 \\
Lowokaru & 2.96 & 3.30 & 3.07 & 3.24 & 3.08 & 2.62 & 2.85 & 2.77 & 2.91 & 2.68 \\
Sukun & 3.28 & 3.45 & 3.16 & 2.73 & 2.92 & 2.06 & 2.43 & 2.63 & 2.52 & 1.87 \\
Klojen & 3.29 & 3.66 & 3.29 & 2.71 & 3.40 & 2.76 & 3.02 & 3.15 & 3.38 & 2.91 \\
Rata2 & 3.16 & 3.53 & 3.18 & 2.92 & 3.13 & 2.54 & 2.92 & 2.96 & 2.99 & 2.43 \\
\hline
\end{tabular}

Berdasarkan table diatas dapat disimpulkan bahwa :

Tabel 18. Peta Kesulitan Guru Menurut Guru SD Di Kota Malang point 11 - 20

\begin{tabular}{|c|c|}
\hline 11 & $\begin{array}{l}\text { Cukup banyak guru yang menyatakan muridnya lebih suka saya beri tugas untuk mencari teori } \\
\text { sendiri }\end{array}$ \\
\hline 12 & $\begin{array}{l}\text { Cukup banyak guru yang merasa tidak familiar dengan kurikulum 2013, memang pada saat peneli- } \\
\text { tian dilakukan kurikulumn } 2013 \text { masih baru saja dilaksanakan pada sekolah dan kelas tertentu }\end{array}$ \\
\hline 13 & 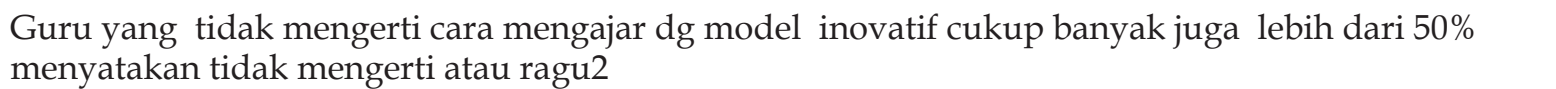 \\
\hline 14 & $\begin{array}{l}\text { th RP dengan model inovatif kurang dari } 50 \% . . . \text { masih lebih ban- } \\
\text { membuat RPP inovatif }\end{array}$ \\
\hline 15 & $\begin{array}{l}\text { materi tepat waktu jika memakai model "student } \\
\text { n kelompok }\end{array}$ \\
\hline 16 & Sebagian besar guru sudah memakai pendekatan apersepsi inovatif untuk membuka pelajaran \\
\hline 17 & $\begin{array}{l}\text { Sebagian besar guru tidak merasa sulit untuk melakukan perencanaan materi dengan berbagai } \\
\text { model pembelajaran inovatif }\end{array}$ \\
\hline 18 & $\begin{array}{l}\text { Sebagian besar guru tidak merasa sulit untuk melaksanakan materi dengan berbagai model pem- } \\
\text { belajaran inovatif }\end{array}$ \\
\hline 19 & $\begin{array}{l}\text { Sebagian besar guru merasa untuk melaksanakan materi dengan berbagai model pembelajaran } \\
\text { inovatif cukup menyita waktu }\end{array}$ \\
\hline 20 & $\begin{array}{l}\text { Sebagian besar guru merasa untuk melakukan penguatan dan tehnik bertanya mempunyai cukup } \\
\text { waktu }\end{array}$ \\
\hline
\end{tabular}

Analisis Faktor Kesulitan Guru SD Negeri Kota Malang untuk Melakukan Pembelajaran Inovatif di Kelas

Dari 20 faktor yang diduga merupakan kesulitan guru dalam menerapkan PBM inovatif dianalisis dengan Regresi Berganda metode Durbin Watson didapatkan hasil sebagai berikut:
Berdasarkan table diatas disimpulkan bahwa dari 20 faktor ada 2 faktor yang dianggap berpengaruh terhadap model pembelajaran inovatif dikelas yakni pembuatan RPP fdan variable nomer 6 kepercayaan guru bahwa siswa mampu untuk diajak melakukan model PBM inovatif berbasis konstruktivisme.

Tabel 19. Variables Entered/Removed ${ }^{a}$

\begin{tabular}{clcl}
\hline \multirow{2}{*}{ Model } & \multicolumn{1}{c}{$\begin{array}{c}\text { Variables } \\
\text { Entered }\end{array}$} & $\begin{array}{c}\text { Variables } \\
\text { Removed }\end{array}$ & \multicolumn{1}{c}{ Method } \\
\hline 1 & RPP1 & & Stepwise (Criteria: Probability-of-F-to-enter $<=.050$, \\
& SSWAKON- & Probability-of-F-to-remove $>=.100)$. \\
2 & STRUK6 & Stepwise (Criteria: Probability-of-F-to-enter $<=.050$, \\
& & Probability-of-F-to-remove $>=.100)$. \\
\hline
\end{tabular}

a. Dependent Variable: PBM 
Tabel 20. Model Summary ${ }^{\mathrm{c}}$

\begin{tabular}{cccccc}
\hline Model & $\mathbf{R}$ & R Square & $\begin{array}{c}\text { Adjusted R } \\
\text { Square }\end{array}$ & $\begin{array}{c}\text { Std. Error of the } \\
\text { Estimate }\end{array}$ & Durbin-Watson \\
\hline 1 & $.213^{\mathrm{a}}$ & .045 & .038 & 23.134 & \\
2 & $.285^{\mathrm{b}}$ & .081 & .066 & 22.788 & .575 \\
\hline
\end{tabular}

a. Predictors: (Constant), RPP1

b. Predictors: (Constant), RPP1, SSWAKONSTRUK6

c. Dependent Variable: PBM

Berdasarkan table 4.45 maka didapatkan hasil bahwa pengaruh dari pembuatan RPP sebesar $21 \%$ dan kepercayaan guru terhadap kemampuan siswa $28.5 \%$
$41.568+4.873 X$ yang bisa diterjemahkan bahwa

$\mathrm{PBM}$ Inovatif dikelas $=41,568+4.873 \mathrm{RPP}$ yang disiapkan

Tabel 21. ANOVA ${ }^{c}$

\begin{tabular}{ccccccc}
\hline & Model & Sum of Squares & df & Mean Square & F & Sig. \\
\hline 1 & Regression & 3101.970 & 1 & 3101.970 & 5.796 & $.018^{\mathrm{a}}$ \\
& Residual & 65294.690 & 122 & 535.202 & & \\
& Total & 68396.660 & 123 & & & $.006^{\mathrm{b}}$ \\
2 & Regression & 5563.371 & 2 & 2781.685 & 5.357 & \\
& Residual & 62833.289 & 121 & 519.283 & & \\
& Total & 68396.660 & 123 & & & \\
\hline
\end{tabular}

a. Predictors: (Constant), RPP1

b. Predictors: (Constant), RPP1, SSWAKONSTRUK6

c. Dependent Variable: PBM

Berdasarkan table Anova tersebut didapatkan Fsig $0.018 \leq 0.05$ untuk RPP dan Fsig 0.06 $\leq 0.05$ untuk kepercayaan guru yang berarti 2 variabel tersebut layak untuk di uji regresi.
2) Untuk Variabel KepercayaanGuru Terhadap Kemampuan Siswa Untuk menggunakan model konstruktivisme didapatkan tsiq 0.03 $\leq 0.05$ berarti ada pengaruh dari Kepercayaan

Tabel.22.Coefficients ${ }^{a}$

\begin{tabular}{ccccccc}
\hline \multirow{2}{*}{ Model } & \multicolumn{2}{c}{ Unstandardized Coefficients } & $\begin{array}{c}\text { Standardized } \\
\text { Coefficients }\end{array}$ & \multirow{2}{*}{$\mathbf{t}$} & Sig. \\
\cline { 3 - 5 } & & $\mathbf{B}$ & Std. Error & Beta & & \\
\hline \multirow{2}{*}{1} & (Constant) & 41.568 & 7.493 & & 5.547 & .000 \\
& RPP1 & 4.873 & 2.024 & .213 & 2.407 & .018 \\
2 & (Constant) & 52.686 & 8.975 & & 5.870 & .000 \\
& RPP1 & 6.364 & 2.108 & .278 & 3.019 & .003 \\
& SSWAKONSTRUK6 & -5.247 & 2.410 & -.201 & -2.177 & .031 \\
\hline
\end{tabular}

a. Dependent Variable: PBM

Berdasarkan hasil analisis regresi berganda durbin Watson didatkan kesimpulan sebagai berikut :

1) Untuk Variabel RPP didapatkan tsig $0.018 \leq$ 0.05 berarti ada pengaruh dari pembuatan RPP terhadap Pola pembelajaran inovatif guru dikelas. Dengan garis regresinya $\mathrm{Y}=$
Guru Terhadap Kemampuan Siswa Untuk menggunakan model konstruktivisme terhadap Pola pembelajaran inovatif guru dikelas.

3) Garis regresi untuk dua variable yang berpengaruh tersebut adalah $\mathrm{Y}=52.688+$ 6.364X1 -5.247X2 
$60 \mid$ Yulita Pujiharti, Loesita Sari, \& Nurrahman, Analisis Faktor Kesulitan Guru SD dalam ...

Itu berarti secara bersama sama dua variable tersebut berpengaruh terhadap pola pembelajaran inovatif dikelas. Hal itu berarti bila guru tidak merasa kesulitan membuat RPP Inovatif serta guru percaya bahwa siswanya bisa diajak untuk menjalankan PBM berbasis konstruktivisme, maka PBM Inovatif berbasis konstruktivisme bisa berjalan.

Garis regresi dari dua variable tersebut diatas bisa digambarkan sebgai berikut :
Sedangkan 18 variabel lainnya yang diduga berpengaruh terhadap PBM INovatif dikelas ternyata dikeluarkan sehingga 18 variabel yang lain tidakada pengaruhnya terhadap PBM Inovatif yang dilakukan guru dikelas. 18 variabel tersebut mempunya Sig $t \geq 0.05$ seperti dibawah ini :

Normal P-P Plot of Regression Standardized Residual

Dependent Variable: PBM

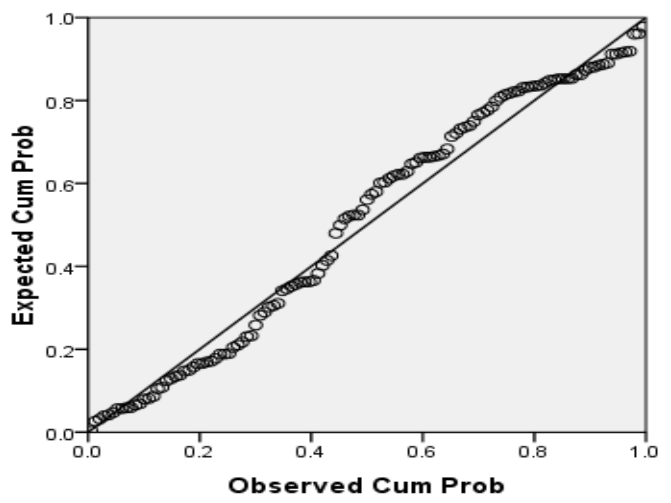

Tabel 23. Excluded Variables ${ }^{c}$

\begin{tabular}{|c|c|c|c|c|c|c|}
\hline & Model & Beta In & $\mathbf{t}$ & Sig. & $\begin{array}{l}\text { Partial } \\
\text { Correla- } \\
\text { tion }\end{array}$ & $\begin{array}{c}\text { Collinearity Statistics } \\
\text { Tolerance }\end{array}$ \\
\hline \multirow[t]{19}{*}{1} & WAKTU2 & $-.002^{\mathrm{a}}$ & -.023 & .982 & -.002 & 1.000 \\
\hline & RUMIT3 & $-.045^{\mathrm{a}}$ & -.496 & .621 & -.045 & .972 \\
\hline & BIAYA4 & $.007^{\mathrm{a}}$ & 078 & .938 & .007 & 1.000 \\
\hline & PENGET5 & $-.020^{\mathrm{a}}$ & -.220 & .826 & -.020 & .914 \\
\hline & SSWAKONSTRUK6 & $-.201^{a}$ & -2.177 & .031 & -.194 & .895 \\
\hline & GURUSUKACERAMAH7 & $.029^{\mathrm{a}}$ & .330 & .742 & .030 & .999 \\
\hline & RPPTERSEDIA8 & $.138^{\mathrm{a}}$ & 1.546 & .125 & .139 & .970 \\
\hline & RUANG9 & $-.040^{\mathrm{a}}$ & -.449 & .654 & -.041 & .999 \\
\hline & SSWASUKACERAMAH10 & $-.054^{\mathrm{a}}$ & -.606 & .546 & -.055 & .993 \\
\hline & SSWSKCARISENDIRI11 & $-.166^{\mathrm{a}}$ & -1.854 & .066 & -.166 & .955 \\
\hline & KUR13NOFAM12 & $-.059^{a}$ & -.666 & .507 & -.060 & .998 \\
\hline & TDKNGERTIKUR2013 & $-.096^{\mathrm{a}}$ & -1.080 & .282 & -.098 & .998 \\
\hline & RPP201314 & $.024^{\mathrm{a}}$ & .271 & .787 & .025 & .983 \\
\hline & TDKTEPATWAKTU15 & $-.005^{a}$ & -.058 & .954 & -.005 & .887 \\
\hline & APERSEPSI16 & $-.080^{\mathrm{a}}$ & -.904 & .368 & -.082 & .995 \\
\hline & $\begin{array}{l}\text { PERENCANAANRU- } \\
\text { MIT17 }\end{array}$ & $.021^{\mathrm{a}}$ & .229 & .820 & .021 & .912 \\
\hline & $\begin{array}{l}\text { PELAKSANAANRU- } \\
\text { MIT18 }\end{array}$ & $-.081^{\mathrm{a}}$ & -.876 & .383 & -.079 & .913 \\
\hline & WAKTUMATERI19 & $-.105^{a}$ & -1.142 & .256 & -.103 & .931 \\
\hline & KETBERTANYA20 & $-.152^{\mathrm{a}}$ & -1.736 & .085 & -.156 & .999 \\
\hline
\end{tabular}




\begin{tabular}{llrrrr}
\hline 2 WAKTU2 & $-.021^{\mathrm{b}}$ & -.239 & .812 & -.022 & .990 \\
RUMIT3 & $-.019^{\mathrm{b}}$ & -.216 & .830 & -.020 & .954 \\
BIAYA4 & $.006^{\mathrm{b}}$ & .070 & .944 & .006 & 1.000 \\
PENGET5 & $.039^{\mathrm{b}}$ & .412 & .681 & .038 & .840 \\
GURUSUKACERAMAH7 & $.043^{\mathrm{b}}$ & .494 & .622 & .045 & .993 \\
RPPTERSEDIA8 & $.136^{\mathrm{b}}$ & 1.542 & .126 & .139 & .970 \\
RUANG9 & $-.064^{\mathrm{b}}$ & -.724 & .470 & -.066 & .984 \\
SSWASUKACERAMAH10 & $-.072^{\mathrm{b}}$ & -.823 & .412 & -.075 & .985 \\
SSWSKCARISENDIRI11 & $-.129^{\mathrm{b}}$ & -1.417 & .159 & -.128 & .907 \\
KUR13NOFAM12 & $-.041^{\mathrm{b}}$ & -.470 & .639 & -.043 & .989 \\
TDKNGERTIKUR2013 & $-.074^{\mathrm{b}}$ & -.841 & .402 & -.077 & .984 \\
RPP201314 & $.013^{\mathrm{b}}$ & .144 & .885 & .013 & .979 \\
TDKTEPATWAKTU15 & $-.014^{\mathrm{b}}$ & -.154 & .878 & -.014 & .885 \\
APERSEPSI16 & $-.053^{\mathrm{b}}$ & -.600 & .550 & -.055 & .973 \\
PERENCANAANRU- & $.016^{\mathrm{b}}$ & .171 & .865 & .016 & .911 \\
MIT17 & & & & & .912 \\
PELAKSANAANRU- & $-.089^{\mathrm{b}}$ & -.977 & .331 & -.089 & .931 \\
MIT18 & $-.102^{\mathrm{b}}$ & -1.136 & .258 & -.103 & .997 \\
WAKTUMATERI19 & $-.144^{\mathrm{b}}$ & -1.661 & .099 & -.150 & \\
KETBERTANYA20 & & & & &
\end{tabular}

a. Predictors in the Model: (Constant), RPP1

b. Predictors in the Model: (Constant), RPP1, SSWAKONSTRUK6

c. Dependent Variable: PBM

\section{KESIMPULAN DAN SARAN}

Berdasarkan analisis data yang telah dilakukan maka diperoleh kesimpulan sebagai berikut:

1. Peta pola mengajar guru yang paling inovatif adalah di Kecamatan Blimbing, sedangkan di Kecamatan Lowokwaru dan Kedungkandang sebagian besar guru cara mengajarnya sudah inovatif, untuk di Kecamatan Klojen dan Kecamatan Sukun pola menagajar guru masih Belum Inovatif.

2. Guru SDN di Kota Malang menganggap bahwa tingkat kesulitan perencaan dan pelaksanaan model pembelajaran inovatif berada pada level sedang.

3. Variabel yang berpengaruh terhadap Pola Pembelajaran Inovatif berbasis Konstruktivisme adalah variable RPP dan Kepercayaan guru terhadap kemampuan siswa untuk melakukan PBM Inovatif berbasis konstruktivisme. Sedangkan 18 prediktor yang lain dianggap tidak berpengaruh.

\section{SARAN :}

1. Pada saat penelitian kurikulum 2013 masih dalam masa sosialisasi, dimana kurikulum 2013 sebenarnya termasuk model pembelajaran inovatif, sehingga disarankan untuk meneliti apakah dengan kurikulum 2013 guru bisa melaksanakannya

2. Disarankan untuk membuat buku pegangan guru sesuai bidang studi untuk melaksanakan model pembelajaran inovatif

3. Contoh dalam bentuk film pemodelan bisa menambah referensi guru.

\section{DAFTAR RUJUKAN}

2007.Rubrik Penilaian Portofolio Sertifikasi Guru Dalam Jabatan. Jakarta: Depdiknas 2006.Panduan Penyusunan Kurikulum Tingkat Satuan Pendidkan. 2006. Badan Standar Nasional Pendidikan. 2005.Peraturan Pemerintah No. 19 tahun 2005 tentang Standar Nasional Pendidikan. Badan Standar Nasional Pendidikan

2003.Undang-undang No. 20 Tahun 2003 tentang Sistem Pendidikan Nasional. Badan Standar Nasional Pendidikan

Anderson, R. H., 1986. Pemilihan dan Pengembangan Media untuk Pembelajaran. Jakarta: Rajawali Pers.

Corey, S. M., 1967. "The Natur of Intruction" in 
$62 \mid$ Yulita Pujiharti, Loesita Sari, \& Nurrahman, Analisis Faktor Kesulitan Guru SD dalam ...

Programed Instruction, 66 tahun Year book, Part II, of the National Society for the Study of Education. Chicago: University of Chicago Press.

Dedi Supriadi (Editor). 2003. Guru Di Indonesia, Pendidikan, Pelatihan dan Perjuangan Sejak Zaman Kolonial Hingga Era Reformasi. Jakata: DirektoratTenaga Kependidikan.

Dedi, S. 1998. Mengangkat Citra dan Martabat Guru. Yogyakarta: Adicita

Degeng, I. N. S. 1991. Karakteristik Belajar Siswa Berbagai Perguruan Tinggi. Laporan Penelitian. Depdikbud Dikti PTBAU/ IUC (Bank Dunia XVIII).

Gagne, R. M. 1985. The Conditions of Learning. New York:Holt Renehart and Winston.

Hall, G. E. (1986). Competency - Base Education: A Process for the improvement of education. New Jersey : Englewood Cliffs, Inc.

Heinich, R., Molenda, M., Tussel, J.D. and Smaldino, S. E. 1996. Instructional Media and Technologies For Learning. New Jersey: A Simon \& Schuster Company.

Johnson, R. T. \& Johnson, D. W. 2000. Cooperative Learning Centerat University ofMinnesota, (Online), www.clcrc, diakses 10 Juli 2000).

Johnson, N. And Wichern, D. 1998. Applied Multivariate Statistical Analysis, PrenticeHall, Englewood Cliffs, N.J.

Lemlech. J. K., 1994. Curriculum and Instructional Methods for the Elementary and Middle
School (Third Edition). New York: Macmillan College Publishing Company.

Merryfield, M. M., Ellaine J., and Sarah Pickert (1997). Preparing teachers to teach global perspectives: A Handbook for teacher educators. California: Carwin Press, Inc.

Nurhadi, S., Agus G. 2003. Pembelajaran Kontekstual dan Penerapannya dalam KBK. Malang: Penerbit Universitas Negeri Malang.

Orlich, D. C., et al. 1998. Teaching Strategies: A Guide to Better Instruction $\left(5^{\text {th }}\right.$ edition). New York: Houghton Mifflin Company.

Proyek Development for Undergraduate Education (DUE) - Like Universitas Indonesia. 2002. Panduan Pelaksanaan Collaborative Learning $\mathcal{E}$ Problem Based Learning. Depok : Universitas Indonesia.

Slavin, R. E. 1995. Cooperative learning, Theory, Research, and Pactice ( $2^{\text {nd }}$ ed). Boston: Allyn and Bacon.

Sudarsono, FX. 1996/1997. Pedoman PTK Bagian Kedua: Rencana, Desain dan Implementasi. Jakarta: Dirjen Dikti, Departemen Pendidikan Nasional.

Jones, W. P. (1981) Writing Scientific Papers and Report, Iowa: WM C Brown Company Publisher.

Tompkins, G. E, 1990. Teaching Writing Balancing Process and Product, New York: Macmillan Publishing Company. 